\title{
Vidas Sob o Signo do Encanto: ETHOS ESTÉTICO NOS OFÍcIOS ARTÍsTICOS da Arte do Carnaval Carioca ${ }^{1}$
}

\author{
Edson Silva FARIAS*
}

\begin{abstract}
RESUMO: Neste artigo importa discutir: no curso da discussão da sociologia da gloria e do reconhecimento, é possível estabelecer correlações entre uma estética tendo por fundamento o impacto das aparências em grandes multidões e um possível ethos atravessando escalas e circuitos de diferentes atividades, mas cuja identidade é fortemente definida pela tônica posta no encanto, na condução recursiva a sentidos orientadores dos emaranhados dos atos?
\end{abstract}

PALAVRAS-CHAVES: Reputação. Arte do Carnaval. Ethos Artístico. Ofícios artísticos. Cultura Estética.

Em sintonia com o propósito de construir trajetórias sociobiográficas voltadas à pesquisa de formações de personalidades artísticas no escopo da cultura estética da arte do carnaval ${ }^{2}$, neste artigo importa discutir: no tocante à sociologia da gloria e do reconhecimento, diante de assimetrias referentes às margens de imposição de vontade, é possível estabelecer correlações entre uma estética tendo por fundamento o impacto das aparências em grandes multidões e um possível ethos atravessando escalas e circuitos de diferentes atividades? Sabendo-se que a identidade do grupo artístico enfocado é definida pela tônica posta no encanto, isto quanto à condução

\footnotetext{
UnB - Universidade de Brasília. Departamento de Sociologia. Programa de Pós-Graduação em Sociologia.nilosed@gmail.com. https://orcid.org/0000-0002-9406-3269.

1 Uma versão preliminar deste texto foi apresentada à Mesa Reconfigurações do Consumo Cultural, durante o Seminário Anual GEPRACC, PRCATIC, SESC-SP, entre 20 e 21 de outubro de 2016 - Centro de Pesquisa e Formação do SESC, São Paulo.

2 Este texto divulga resultados do projeto de pesquisa Estilemas Artísticos no Ofício de Carnavalesco na Cultura Popular Urbana do Espetáculo no Rio de Janeiro, que conta com financiamento do CNPq, na modalidade de bolsa de produtividade em pesquisa (2014-2017).
} 
recursiva a sentidos orientadores dos emaranhados dos atos que delineiam ofícios artísticos inscritos no sistema ocupacional da dinâmica produtiva do Desfile de Carnaval-Espetáculo.

Em alguma medida, tomamos de empréstimo à Nathalie Heinich (1991) aspectos do seu modelo analítico de uma antropologia da admiração, no momento em que o objeto de conhecimento diz respeito aos processos cruzados de construção do valor da glória artística do gênero Desfile de Carnaval e dos ofícios que o realizam. Entretanto, a aposta teórica aqui se ergue em um terreno incerto, afinal como teremos oportunidade de expor adiante -, há celeumas internas, igualmente de fora desse domínio cultural, no que toca atribuir valor artístico para o desfile e seus artífices. Enfim, pesa sobre o contexto empírico, em que realizamos a pesquisa, a sombra da ilegitimidade artística.

Frente aos pontos arrolados nesta introdução, dois objetivos são perseguidos neste texto: a) objetivar alguns dos canais que se manifestam importantes na construção das reputações artísticas nesse mundo artístico carnavalesco; b) postos tais vasos comunicantes, procurar-se-á observar e comentar as diferentes referências feitas à forma artística própria ao Desfile do Carnaval-Espetáculo, mas nas maneiras de afirmar ou refutar as reputações daqueles que participam desse círculo, na medida mesma em que são perseveradas as distinções entre os de dentro e aqueles classificados como alheios aos possíveis limites do espaço da arte do carnaval.

\section{O tempo no compasso de uma roda de conversa}

Diante do objetivo de examinar os círculos internos à arte do carnaval carioca, uma das metas consistiu em construir trajetórias sociobiográficas de agências humanas que ocuparam ou ocupam a posição-função artística do carnavalesco no sistema de práticas lúdico-estéticos populares do Desfile de Carnaval das Escolas de Samba do Rio de Janeiro da perspectiva da materialização dos seus respectivos estilemas em formas plástico-visuais. Assim, exigia-se iniciar percursos de conversações com os(as) artistas. Antes de atentar às implicações metodológicas de entabular as conversas, logo se colocou o problema: como chegar até eles(as)? Embora o modo de aproximação do contexto empírico enfocado na nossa pesquisa não abarcasse a semântica literal de uma etnografia antropológica, compartilhamos de alguns entre os sentimentos envolvidos com as decisões e efeitos relativos à adoção de alternativas de aproximação aos ambientes do cruzamento de convivências constituintes do segmento carnavalesco abordado, no Rio de Janeiro.

Desde Malinowski (1976), incorporada à maneira de um imperativo ético e metodológico, a retórica dos relatos antropológicos verbaliza os dilemas e soluções encontradas por antropólogos(as), em meio ao movimento de aproximação do seu 


\section{Vidas Sob o Signo do Encanto: Ethos estético nos oficios artísticos da Arte do Carnaval Carioca}

contexto de pesquisa. No instante em que a convivência com os nativos de outra cultura impõe-se chave à tarefa etnográfica de apreender o que faz especifico um modo de vida no entretimento de planos e manifestações, o emprego das noções de distância e proximidade ultrapassa as necessidades vinculadas à orientação sociogeográfica, porque nele estão inseridas antinomias afetivas e morais, como simpatia versus repulsão, encanto versus desencanto. Embutidas no problema da alteridade como inaugural e nevrálgico à cultura disciplinar antropológica, tais disjuntivas podem interferir no alcance da cognição pretendida, isso em razão das inconveniências que poderão ocorrer no atendimento dos critérios de objetividade da inferência científica. Em se tratando do nosso contexto de pesquisa, não é mera frivolidade, portanto, a recorrência das descrições de caminhos - muitas das vezes, verdadeiras ginásticas - percorridos por pesquisadores(as) para obter senhas que os autorizassem frequentar as relações sociohumanas internas às Escolas de Samba cariocas e aos seus desfiles. O relato de Santos (2006) é ilustrativo do nuance de situações mesclando acasos, pináculos de dramaticidade e o papel estratégico desempenhado por pessoas cujo prestígio mais que abrir portas, contribui para desfazer as suspeitas que cercam os estranhos(as) que procuram proximidade com os círculos dos(as) artistas do carnaval.

Se, como já aludimos, uma das nossas metas consistia na construção de sociobiografias, à luz do interesse na remonte de linhagens geracionais no ofício de carnavalesco, a trajetória de Joãosinho Trinta ${ }^{3}$ foi o ponto de partida escolhido. Afinal, fossem as lembranças das conversas nos bastidores do carnaval das escolas de samba, que tive na década de 1990, fossem em diálogos preliminares ocorridos quando nós tateávamos o terreno da pesquisa mais recente, esse nome sempre aparecia na posição de um arquétipo do ofício. Inclusive, a consulta etimológica do termo carnavalesco apenas ratificou a mesma recorrência, pois a semântica do termo abarcando a figura individualizada do profissional dedicado ao preparo de

\footnotetext{
3 Maranhense de origem, João Jorge Trinta chegou ao Rio de Janeiro no início da década de 1950 com o propósito de se tornar bailarino do Teatro Municipal carioca. Frustrada a continuidade no corpo de balé da prestigiada instituição cultural, ele passou a atuar como aderecista do setor de óperas do mesmo teatro. O encontro com o cenógrafo e professor da Escola de Belas Artes Fernando Pamplona, Ihe abre as portas do carnaval. Por anos atuou como auxiliar da equipe liderada pelo mesmo Pamplona e o figurinista Arlindo Rodrigues, a qual ganhou notoriedade na proposição de execução de projetos de decoração carnavalesca de bailes prestigiados, além de algumas das ruas e avenidas em que se desenrolava a festa na cidade, principalmente, como o núcleo do Grupo do Salgueiro - círculo reunindo artistas plásticos e visuais que se firmou como referência nas transformações estéticas ocorridas nos desfiles das escolas de samba, entre as décadas de 1960-1970. Com a saída de Pamplona e Rodrigues, Trinta assumiu o posto de comando do carnaval da escola de Samba Acadêmicos do Salgueiro, na qual obtém um bicampeonato entre 1974-1975. Transfere-se para a escola de Samba Beija-Flor e lá, contribuiu para transformar essa desconhecida agremiação em tricampeã (1976 a 1978). Sua fama vem a reboque do reconhecimento da sua participação na fixação do Desfile de Carnaval das Escolas de Samba como um superespetáculo notabilizado pela centralidade obtida pelos carros alegóricos, que se multiplicam, tornando-se maiores, com maior densidade e volume cênico (FARIAS, 2012, RIBEIRO; FARIAS; PORFIRO, 2017).
} 
fantasias e alegorias em concordância com um enredo anualmente renovado, apenas se dá por volta da década de 1980, mas sob o signo da repercussão da pessoa de Trinta (FARIAS, 2012). Devido à sua morte, em dezembro de 2011, a tarefa que nos colocamos, então, foi ir à busca dos que orbitaram em torno do artista ao longo do seu trajeto nos barracões das escolas de samba.

Situada em 92.200 mil metros quadrados, na Zona Portuária do Rio de Janeiro, a Cidade do Samba abriga os 14 galpões ocupados pelos barracões - locais de produção das alegorias e fantasias - dos grêmios que desfilam na divisão principal do concurso festivo das escolas de samba. Ficávamos numa das duas áreas cobertas por grandes lonas localizadas na praça central do espaço - permanecemos naquela voltada para a realização de shows. Por acomodar lojas onde são comercializados alimentos e bebidas, tendo mesas cercadas de cadeiras, na rotina de fabrico e trabalho, ali se dá a maior concentração de pessoas vindas dos barracões, mas também quem está no local para conversar com alguém na expectativa de ter a oportunidade de expor produtos ou serviços, além de componentes das escolas que foram convocados para ensaiar ou experimentar indumentárias e, também, gente movida pela curiosidade acerca das grandes peças alegóricas que se escondem por trás dos imensos portões à frente dos galpões. Ante esse panorama, certo estranhamento decorria do nosso comparecimento àquele local - digo do André e eu, ao lado de jornalistas e outros pesquisadores -, pois estávamos incluídos entre os que justificavam a presença em função de finalidades diante das quais os fins perseguidos pelas tarefas executadas na Cidade do Samba, são meios. Investidos dessa distância, uma vez pela manhã e a outra na hora do almoço, separadamente, conversamos com dois carnavalescos (uma mulher e um homem), ambos não mais atuando na linha de frente da elaboração dos enredos, tornaram-se crítico(a)/comentaristas dos desfiles pela TV. Falamos também com três artesãos homens cujas respectivas iniciações se deram sob o comando de João Trinta.

Posto aquele início, nossa expectativa era seguir um trajeto de escuta de relatos individualizados, em situações esparsas. No entanto, para nossa surpresa, o fluxo foi interrompido a partir do agendamento de uma possível entrevista com homem que por 20 anos, auxiliou JoãoTrinta na concepção de figurinos. Diferente das outras situações de entrevista, essa estava marcada para as 18:00 horas. Se embaixo da lona ainda estava muito quente, pois o sol permanecia ardente, a sensação de calor era amortecida por conta de já haver áreas mais sombreadas e até o ar circular mais intenso àquela altura do dia na Cidade do Samba. A concorrência de pessoas no local permanecia acirrada, só que se alterara o perfil dos frequentadores: ao final do horário do expediente de trabalho, diminuía os vindos dos barracões estes passavam em grupo na direção externa da Cidade do Samba na procura das muitas linhas de ônibus que circulam nas vias laterais que os levassem para casa ou atravessaria o túnel Lauro Sodré, situado sob o Morro da Providência, a caminho 


\section{Vidas Sob o Signo do Encanto: Ethos estético nos oficios artísticos da Arte do Carnaval Carioca}

da Estação Ferroviária Central do Brasil ou da estação do metroviário, às margens das pistas da Avenida Presidente Vargas, no centro da cidade. A afluência maior agora era dos curiosos, sobretudo, dos componentes das escolas que estavam ali para ensaiar e experimentar roupas. Notavam-se, igualmente, rodas formadas em torno das mesas pelas direções das agremiações que, muitas das vezes, misturavamse. Daí porque os traços fisionômicos ficaram mais familiares: os rostos revelavam nomes de artistas e dirigentes conhecidos, por serem veiculados pela TV e/ou nas redes sociais na internet.

Mais ruidosa, a cena do ambiente agora comportava uma descontração não vista durante a primeira parte do dia. As tulipas de vidro tomadas de chope, as garrafas de cervejas ladeadas por copinhos de plástico ou as latinhas coloridas, dispostas sobre as mesas, denunciavam o aumento bem significativo no consumo de bebidas alcoólicas. Encontramos Urano ${ }^{4}$, sentado diante de uma dessas mesas, tomando goles de cerveja num copo. Ele bebia acompanhado de duas mulheres - a escultora Antígone e a alegorista Penélope. Feitas rápidas apresentações, seguidas de igualmente sumárias descrições da justificativa para o encontro, juntamo-nos a eles. Embora, de início, a falta de intimidade houvesse gerado certo desconforto manifesto nas sucessivas pausas no fluxo das conversas, não demorou para estarmos enturmados e, logo, estivéssemos compartilhando de um leque de temas nucleado pela questão do carnaval das escolas de samba, mas estendendo-se, entre outros, até as lembranças relativas às motivações que conduziram ao interesse pessoal pelo evento-espetáculo, aos percursos profissionais, passando pela formação universitária até a recordação cantada de antigos sambas-enredos. Ao quinteto inicial se juntaram outros(as), os quais permaneceram até o fim do encontro, enquanto houve aqueles(as) que não se demoraram. Íamos sendo apresentados a outros profissionais do carnaval - escultores(as), pintores de arte, aderecistas, alegoristas, figurinistas, iluminadores e muitos(as) outros(as). Regados à cerveja e ao consumo de cigarros, em meio à descontração nos gestos e falas, de um modo geral, os tópicos abordados cultivaram a interlocução comum, em especial questões implicadas às dificuldades à realização do carnaval que se aproximava e à incerteza quanto ao futuro dos desfiles. Porém, algumas das vezes, certa pulverização dominou o curso das conversas, notadamente quando se tratou de detalhes do trabalho que ora se desenvolvia ou quando, de maneira crítica, tematizava-se o trabalho de alguém que estava ausente.

Tomados pela empolgação da conversa, não atentamos ao esvaziamento paulatino do local, o que só ocorreu quando o garçom do bar veio notificar que deveríamos pagar a conta do que foi gasto, mas poderíamos permanecer sentados ali, desde que trocássemos os copos de vidros pelos de plástico e, ao final, empilhássemos as

\footnotetext{
4 Por razões de natureza ética, visando não expor nossos(as) interlocutores(as), adotamos nomes fictícios.
} 
mesas e cadeiras num canto onde já estavam tantas outras dispostas. Àquela altura, por volta das duas da manhã, o silêncio era interrompido apenas pela manobra de algum dos carros alegóricos que estavam estacionados em frente ou dentro dos galpões. Ainda que o anúncio do horário causasse certo espanto, a conversa se estendera até por volta das quatro e meia.

Depois que vimos entrarem tanto Urano quanto Antígone e Penélope nos respectivos táxis, seguimos também à busca de um transporte, a caminhada pelo silêncio das ruas vazias na direção da Avenida Presidente Vargas serviu para, mais que tentar sintetizar, em vão, a experiência daquela noite, exprimíssemos a satisfação gerada e a ciência das oportunidades de diálogos que se abriam a partir dali, com vistas às possibilidades de ingressar em temáticas que, até então, estavam apenas na condição da mera especulação. Viabilizar outros encontros semelhantes àquele se tornou fonte de mútua ansiedade. Contudo, dois dias depois, o sentimento logo se viu debelado em razão do telefonema de Urano, nos convidando para, novamente, "tomar uma" na Cidade do Samba". Sem vacilo, estávamos lá na hora marcada. E episódios assim se repetiram por mais quatro vezes até a semana em que se iniciou o carnaval de 2014. Sendo os encontros retomados por mais três vezes também nos meses de janeiro e fevereiro, mas em 2015.

A certa altura, não se sabe bem por obra de quem, os encontros foram nomeados de roda de conversa do Urano. A silhueta de um ritual de sociabilidade se firmou no compasso em que as convenções referidas às etiquetas comportamentais compartilhadas entre os participantes associaram o querer estar junto, em razão do falar descontraído do carnaval das escolas de samba, com o descompromisso para com as prescrições do relógio que regulam o ritmo do tempo produtivo do trabalho. As rodas se iniciavam ao final da jornada de trabalho nos barracões e vazavam a noite, nunca se encerrando antes das três da manhã. Ao longo das rodas formadas, além do quinteto de participantes da primeira hora, ampliou-se de maneira infinitesimal o número de participantes, o que teve decisiva contribuição no aumento do nosso conhecimento do elenco de oficiais envolvidos com a produção do desfile. E, à contrapartida, descortinaram-se novos temas que foram inseridos na nossa pauta da pesquisa. Embora esses últimos aspectos tenham se mostrado estratégicos nos rumos do problema examinado na pesquisa, aqui reteremos apenas como objeto de interesse a particularidade dos nove encontros aninhados nas noites da Cidade do Samba, entre janeiro e fevereiro de 2014 e 2015. Justifico a escolha, de um lado, sublinhando o impacto dessa série de episódios, por ter revertido àquela expectativa que tínhamos, a princípio, no tocante à natureza da interlocução a ser estabelecida com os círculos de artistas do carnaval; de outro, na medida em que inseriu a polifonia como natureza dessa interlocução, facultou-nos flexibilizar agenda de pesquisa, redefinindo prioridades e, ainda, acrescendo itens, antes sequer imaginados. 


\section{Vidas Sob o Signo do Encanto: Ethos estético nos oficios artísticos da Arte do Carnaval Carioca}

Figura 1: Roda de conversa do Urano - fevereiro de 2015

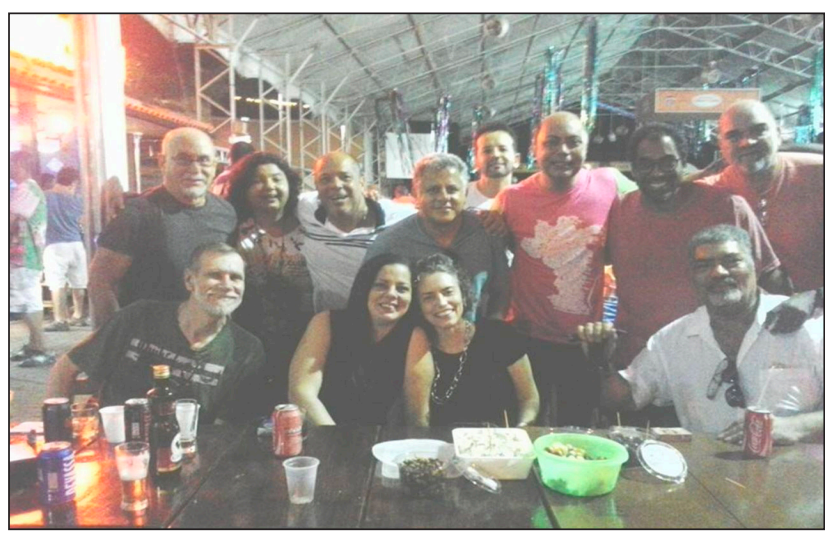

Fonte: Foto de Valtemir Valle (2015).

Por certo, a nossa inclusão nesse círculo de interlocução traz questões espinhosas deflagradas com a presença socioantropológica em situações interculturais, em especial a da tradutibilidade e da textualização do outro; questões postas por antropólogos como James Clifford (1999; 2002). Para os objetivos deste texto, a sucessão dos encontros detém um traço próprio, merecedor de cuidado analítico e interpretativo especial a saber: a condição de fórum interativo-comunicacional em que, focos de interesse dialógico, pessoas e seus fazeres tornavam-se objeto de crivo de pares integrantes de uma mesma comunidade de sentido e, com isso, numa escala nuançada de classificações, estiveram à disposição para sagrações elogiosas ou reprovações vigorosas. Aliando-se, nesta instância, os critérios do mérito ao da moralidade no movimento interlocucional de atribuição de valor, quer dizer, de construção da diferença das tomadas de posição dos artífices focalizados no espaço social de possíveis de produção e visibilização da arte do carnaval.

A partir do segundo encontro, à medida que a noite avançava e os efeitos da cerveja iam se manifestando na maior descontração dos comportamentos, igualmente, obteve discernimento o tópico preferido das conversas: nomes de pessoas que, não presentes à roda, ainda que dela tivessem feito parte, eram lembrados para serem logo avaliados em sua reputação. O crivo era orientado para o seu comportamento nos barracões e, principalmente, ao seu trabalho. Sempre me impressionou como os nomes arrolados eram de conhecimento comum entre as pessoas que estavam reunidas nos nossos encontros - claro, à exceção dos autores deste texto. Mesmo sem pleno consenso, alguns nomes eram merecedores de acentuado respeito; na maioria das vezes, o que se the reprova eram algumas das suas idiossincrasias - atitudes do tipo: "manias de grandeza", "viajandão", "briga à toa". O respeito era indissociável do quesito mérito, portanto, os resultados da atuação profissional desempenhavam 
destacado papel na qualidade conferida à visibilização das pessoas na conversação. Ressaltavam-se, por exemplo, o "traço limpo" de uma, a "autonomia" em tomar decisões de outra, a criatividade daquela para tirar partido de situações adversas ou aquela que "sabe como fazer render o trabalho", mas há também aquela cujo trabalho com a paleta de cores é "fantástico!". Se a sobriedade dos pronunciamentos indexava as classificações mais positivas, por sua vez os tons mais graves da voz e os sorrisos no canto da boca, mesmo as gargalhadas, acompanhados de comentários jocosos, acompanhavam as enunciações que, da mera repreensão, estendiam-se ao achincalhe: "Ah, gente! Esperar o que de fulano? Lembra que ele começou varrendo o chão do barracão", "ele nunca soube desenhar, todo mundo sabe disso", "quando ele conseguiu terminar tudo o que projetou?", "se a figura não sabe o que é uma planta baixa?". Uma vez mais, o trabalho servia de parâmetro no julgamento depreciativo de pessoas. Mas se certa maledicência referida às questões sexuais era recorrente no movimento das conversas, quando se tratava de detratar alguém, acentuava-se a lembrança de episódios envolvendo momentos vexaminosos implicados aos mesmos temas sexuais em que o(a) comentado(a) teve participação. Quando não era algum traço do seu comportamento e/ou aspecto fisionômico que recebia um tratamento malicioso, sempre culminando na detratação calcada na sexualidade. A condição de homossexual masculino de muitos dos oficiais era o alvo predileto dos comentários. As trocas de olhares, as ironias e os sorrisos largos emolduravam o quadro comunicativo da interação, cujo fraseado ia do recorrente "ele não trepa" ao "bichinha intolerante", passando por "peguei ele com fulano atrás do carro (alegórico)."

Tomamos de empréstimo a categoria de ritual de interação ao vocabulário conceitual de Goffman (2011). Segundo informa o autor, a categoria surgiu de acordo com o propósito de construir uma "sociologia das ocasiões", com o relevo analítico depositado nos comportamentos face a face. Ocasiões nas quais as linguagens verbais e não-verbais são requisitadas como fatores fundamentais de articulação dos comportamentos, em obediência ao imperativo de que os indivíduos emitam opiniões acerca de algo. A emissão de opiniões, por sua vez, terá repercussão na avaliação da fachada do interlocutor pelos demais membros da interação, os quais confrontaram as expectativas alimentadas acerca desse posicionamento e a sua realização. Segundo a ilação goffmaniana, a expectativa de êxito e/ou fracasso exerce forte pressão sobre as expectativas do locutor. Este se empenha, portanto, no manejo reflexivo dos enquadramentos moral-normativos, no sentido de antecipar-se e, assim, superar na dramaturgia dos seus atos, as possíveis dificuldades situacionais.

Ainda que a dimensão situacional seja realçada, porém, a argumentação desenvolvida aqui não tem por respaldo teórico a concepção de conversação como posto pela base canônica conceitual nem do interacionismo simbólico tampouco da etnometodologia. Isto porque não é ratificada a chave de acesso à teoria da consciência pelo viés da intersubjetividade. Nossa aposta teórica deposita, sim, 


\section{Vidas Sob o Signo do Encanto: Ethos estético nos oficios artísticos da Arte do Carnaval Carioca}

relevo analítico na pragmática formal da conversação, porque entende os atos de fala como fatores capazes de, para além de se referirem às coisas, produzirem efeitos relativos ao convencimento acerca do que se diz (SEARLE, 1969). Nesse sentido, os atos de fala se definem elemento por excelência de coordenação comunicativa entre as condutas no ritual de sociabilidade, aqui enfocado. Em Pierre Bourdieu (1992), encontramos o empenho em situar a interação simbólica promovida pela interlocução linguística no escopo de disputas de um mercado envolvendo um poder simbólico, logo, é preciso ter em mente que as trocas simbólicas são simultaneamente relações de poder simbólico, nas quais são atualizadas relações de força entre locutores e seus respectivos grupos. Por outro lado, a visada pragmática deixa entrever que, na condição de microcosmo, as situações de conversação não espelham tampouco miniaturizam uma totalidade que as abarcaria. Atento ao caráter mais ou menos contingente, próprio à precariedade desses coágulos micropolíticos, o examinamos como o plano concreto e imediato da realidade sócio-histórica, em que as dinâmicas conversacionais tecem consensos acerca de prestígios e/ou fazem imergir nomes e fazeres na desgraça e, para adiante, os fazer desaparecer na sombra do esquecimento.

De volta à proposição sobre a antropologia da admiração, aplicada à glória do pintor holandês Van Gogh, Nathalie Heinich (1991) adota por procedimentos analíticos os meios pelo qual se constrói o caminho que leva da economia cultura do valor (estético e ético) à economia de mercado dos valores. Sua atenção se aplica sobre a decalagem de ritmos entre os tempos de produção e consagração, em especial, ocupando-se das intervenções dos críticos que, no alongado temporal do pós-morte do artista, contribuíram à formação da lenda que fez cruzar a biografia e as obras na ressignificação da marca Van Gogh como signo de um gênio, destacada pela singularidade subjetiva articulada ao regime modernista de autoria. Com o fito de articular o tratamento dado à construção da glória em Heinich (1991) com o ritual de sociabilidade, aqui examinado, em lugar do tramado de textos escritos ${ }^{5}$, a conversação face a face se antecipa como fator de coordenação de condutas

\footnotetext{
5 Ressaltamos que, de modo algum, desprezamos a importância dessa mesma dimensão no tocante à construção da glória nos círculos próprios à arte do carnaval carioca. Por isso mesmo, ainda que de maneira tácita, impacta os rumos das conversações das quais participamos na Cidade do Samba. Durante o século XX desenvolveu-se uma crônica jornalística especializada nos fazeres imanentes à festa, jogando papel decisivo na tessitura da fama de nomes. Desse modo a mídia impressa, em particular os jornais, estava à frente na produção e repercussão dessas narrativas pelas quais se glorificam e classificam personagens. Atualmente blogues, sites e portais nas redes sociais se impõem como os fóruns estratégicos à focalização prestigiosa. Um índice importante a respeito, são os prêmios concedidos àqueles(as) que teriam se destacados nas noites de desfiles no Sambódromo, tais como: Estandarte de Ouro (Jornal O Globo), Tamborim de Prata (Jornal O Dia). Estrela do Carnaval (Site Carnavalesco), SRZD-Carnaval (Portal SRZD), entre outros. Os(as) membros desses júris compostos por jornalistas e pessoas notabilizadas como autoridades no tema do samba e dos fazeres artísticos carnavalescos, portam a representatividade para deliberar o que é ou não legítimo em termos das escolas de samba.
} 
entretidas na situação de interação e, por isso mesmo, intervém na qualificação/ classificação de pares e suas atividades no espaço de possíveis da arte do carnaval.

Se pensarmos em termos morfológicos, concluímos que, durante as noites nas rodas de conversa de Urano, havia equilíbrio entre os contingentes de homens e mulheres. Em termos étnicos, brancos(as) e mestiços(as) sobressaiam em relação a negros(as), na mesma medida em que os(as) detentores(as) de títulos universitários prevaleciam frente aos(às) demais. Foram poucas ocasiões em que algum(as) dos frequentadores(as) ocupava(m) a faixa etária abaixo dos 40 anos. Quando comparados os itens de categorização social, junto à quase homogeneidade ocupacional dos integrantes, em sua maioria com vínculo empregatício juridicamente informal junto à arte do carnaval, a estratificação etário-geracional concedia certo padrão recursivo na sucessão dos encontros. E, com isso, respaldava identitariamente o grupo. Em parte, a facilidade com a qual compartilhavam lembranças estava à contrapartida de quadros comuns de memória relacionados ao decurso temporal de convivência mútua, tendo por marco inicial os meados da década de 1990. Os filtros mnemônicos, quando acionados, selecionavam os alvos de interesses dos comentários, pouco ou nada se falava do número acentuado de jovens que circulam atualmente em diferentes atividades, no interior dos barracões. Tanto que, ao final do resultado do concurso de 2016, chamou-nos atenção o fato de apenas uma vez, e de maneira sumária, ter escutado alguma referência ao jovem de $34 \operatorname{anos}^{6}$ que, na sua estreia como carnavalesco de uma grande escola, contribuiu para o título da Estação Primeira de Mangueira. Se as consequências do emprego desses filtros concorriam à reiteração da geração de oficiais da arte do carnaval abarcante dos membros da roda de conversa, a funcionalidade de situações (à maneira do nosso ritual de sociabilidade) atuava no reforço da sua representatividade junto aos postos de comando com ingerência na decisão sobre a escolha da mão de obra para compor os quadros funcionais de uma equipe, porque auxiliavam diretamente o(a) artista carnavalesco(a). Ou quando alguns dos integrantes dessa fração geracional não ocupavam, eles mesmos, tais postos. Penso apropriado supor que as ocasiões da roda de conversa, durante aquelas noites na Cidade do Samba, a depender da conjunção contextual de ingredientes favoráveis para lhes garantir o status de espaço de deliberação, não foram elas mesmas oportunas à indicação ou descarte de alguém para o exercício de tal ou qual atividade, em meio às teias de conversas nas quais reputações eram consensualizadas, de modo positivo ou negativo. Levantar essa possibilidade a respeito da autoridade das falas emitidas no tocante à capacidade de

6 Trata-se do cenógrafo e artista plástico Leandro Vieira, que por anos atuou como figurinista integrando equipes lideradas por carnavalescos consagrados e, em 2014, assumiu o comando estético da Escola de Samba Em Cima da Hora, à época desfilando no Grupo de Acesso A do torneio carnavalesco das escolas de samba do Rio de Janeiro. Casado, então, com a primeira porta-bandeira e herdeira de uma das dinastias familiares com forte ressonância na Mangueira, em 2015, ele foi convidado para fazer o carnaval dessa celebrada agremiação. 


\section{Vidas Sob o Signo do Encanto: Ethos estético nos oficios artísticos da Arte do Carnaval Carioca}

gerar efeitos que, do instante em que visibiliza e avalia um nome, reputa-o, deixando em vias de acolhimento ou descarte no espaço de possíveis de posições posicionadas do campo da arte do carnaval das escolas de samba cariocas, requer considerar as propriedades dessas mesmas falas, às quais lhes conferem tamanho potencial de rentabilidade comunicativa.

A atenção socioanalítica a essas propriedades, sem incorrer no risco de substancializá-las, impõe que as situemos nesse espaço de possíveis onde elas se formam e ao se diferenciarem, dispondo-se em relação de desigualdades com outras falas, podem obter dividendos expressivos, na simétrica medida em que estão pressionadas pelo desprestigio da justificativa conferida à sua própria posição artística.

\section{$\mathrm{Na}$ fusão das cidades, disposicionalidade e justificação}

Em As Meditações Pascalianas, Bourdieu (2001) debruça frente ao problema em torno do déficit de justificativa de si, mas o faz tensionando esse tópico (inerente à antropologia filosófica) pelos requisitos da sociologia econômica relacionada à escassez de meios simbólicos. Ele insiste no argumento de que a carência de justificativa consiste em uma das propriedades estruturantes das experiências e dinâmicas sociohumanas. $\mathrm{O}$ autor reserva especial interesse à contradição manifesta no encontro da insuficiência de meios endógenos às pessoas para se autonomear, ou seja, a insuficiência na possibilidade de assegurar autonomia classificatória e avaliativa, e a distribuição desigual de recursos facultativos de conforto ontológico. Portanto, no caudal deste desequilíbrio distributivo, dispõe-se o conflito moral relativo às lutas por reconhecimento no topo entre as questões nevrálgicas enfrentadas por pessoas e grupos, não só pelo direito de dizer e afirmar o que se julga ser, mas igualmente, apelar à legitimidade dos meios expressivos com os quais uma singularidade aparece como objeto de apreciação pública.

A obra de Max Weber (1992), por sua vez, na teoria social, detém a virtude de ter convertido a legitimidade dos ordenamentos de poder em foco de interesse sociológico. Em duas oportunidades distintas da sua obra, ele elabora ilações cujas respectivas repercussões foram decisivas à importância gozada pelo problema da legitimação e legitimidade. Ao tratar das formas de dominação, no escopo da sociologia política, Weber (1992) atenta às justificativas dadas por um ordenamento de poder, no tocante ao seu exercício próprio de dominação. Já nas pesquisas, estudos e reflexões sobre o fenômeno religioso (WEBER, 2006), o autor retoma a discussão em torno das divisões sutis do mundo no movimento pelo qual focaliza as lutas por emancipação travada por representantes de diferentes esferas da experiência social. Nesta última visada, uma vez mais, o olhar sobre as justificativas se faz em consideração do delineamento de cursos precisos de linhas de recursivas 
de condutas, estando estes implicados à proliferação de éticas diferentes e mesmo conflitantes entre si. Seriam esses alguns aspectos emblemáticos da fisionomia adquirida pela modernidade europeia ocidental. Em ambas as apreensões do tema da legitimidade, Weber $(1992,2006)$ operacionaliza o problema sobre as éticas particulares para cercar as maneiras pelas quais posturas convictas e sistemas de crenças se tornam complementares.

A aposta feita pelo mesmo Bourdieu (1992) na ideia de illusio, com a qual adere e elasticiza a refração weberiana em torno das éticas referidas às diferentes esferas da experiência. Enquanto motivação pré-reflexiva com a qual se justifica e abastece a participação nos espaços onde os lances são dados e estratégias são realizadas, na condição de categoria analítica, a illusio corresponde à aspiração do porque se entra e se participa de um jogo cujas fronteiras e regras tendem soar arbitrárias aos que assistem, vendo e sendo vistos como localizados de fora de um específico espaço de posições posicionadas onde se dão posicionamentos. Observa o autor que, em muitos momentos, torna-se insólito ou injustificável, aos de fora, o fundamento acionado para assegurar o status de plausível àquilo que se compartilha como identificado às divisões internas e, também, na triagem do que não pertenceria àquele espaço de possíveis.

Adotando uma perspectiva relacional, no sentido estruturalista de oposições complementares informando posições, quer dizer, diferencialidades significantes, Bourdieu (2007) concebe uma topografia na qual o espaço simbólico (de classificação, ordenação, inteligibilidade e, ainda, reconhecimento) está na contrapartida da posição ocupada pelo agente na teia de distribuição dos recursos sociais. Logo, enquanto espaço de possíveis, no que se refere ao alcance na participação em determinado jogo social, o campo corresponde uma estrutura de relações objetivas, na qual são postos em concorrência capitais simbólicos (de nomeação/ classificação). Está em pauta a conversão de recursos estruturais (à maneira de retenções financeiras e contatos), acumulados por um agente no seu transcurso, em elementos de distinção/reconhecimento (BOURDIEU, 2007). Os capitais simbólicos são especificados à luz das regras de cada um dos campos - a já comentada illusio, enfim, a crença que sustenta a cada respectivo campo (BOURDIEU, 1996). As respectivas dinâmicas dos espaços de possíveis se definem pela depuração do que o distingue e o faz exclusivo e consta do senso de jogo, do saber praticar de todos os que participam e fazem lances nesse espaço social. Conclui Bourdieu (2009) que a história do campo permite atingir os modos de elaboração das pulsões expressivas que decidem as delimitações que tornam o mundo reconhecível, ou seja, natural, em suas diferencialidades práticas. Frente à ignorância característica da entrada e permanência no jogo próprio ao campo, pode-se concluir que nele as lutas sociais (pela afirmação e manutenção da diferencialidade da posição e também da sistemática de posições/oposições em que se inscreve e sua conversão 


\section{Vidas Sob o Signo do Encanto: Ethos estético nos oficios}

artísticos da Arte do Carnaval Carioca

simbólica) estão na raiz de uma condição que se dá como transhistórica, quer dizer, como razão das coisas.

Por sua vez, o que está posto como o objetivo da antropologia da glória, em Boltanski e Thévenot (1991), é como pessoas se ajustam tanto à autoidentificação quanto à reivindicação de grandeza por parte de um indivíduo, no instante em que está em pauta o reconhecimento dessa grandeza por parte de outras pessoas? Grandeza no sentido da altivez interna ao sentimento de dignidade, mesmo da sublimidade, enfim, do que é referente aos bens do mundo, enquanto reconhecimento da honra. Portanto, a grandeza se refere à glória de gozar o respeito mútuo pela autoimagem e proposição de si, em virtude do modo como a estima é afetada pela aprovação moral. E os focos analíticos se voltam para os conflitos em que os contenciosos se enfrentam devido ao posicionamento moral que ocupam na condição de objeto de grandeza ou não. O que entraria em crise, fazendo-se elemento de litígio, são as coordenadas pré-reflexivas de orientação das condutas que definem estas mesmas posições. Seria, nesses momentos críticos, que emergiriam requisições acerca das justificações para se atribuir tal valor a pessoas, objetos e episódios. Cobrando-se, com isso, o critério de que os contenciosos sejam capazes de abandonar o lugar de indivíduos para transcenderem à condição mais generalizada, a qual supõe coalizões que viabilizam a equivalência entre as pretensões de valores e, com isto, requisitam a competência cognitiva e de julgamento dos agentes para tanto cobrarem ajustes quanto eles mesmos realizarem ajustes.

Se os ajustes estão em direta relação com a possibilidade de viabilizar equivalências, para os dois autores, torna-se imperativo demonstrarem como pretensões de validez devem ajustar a incomensurabilidade das conjunturas aos princípios transcendentes de ordenação/coordenação comportamental. No livro De la Justification, inspirando-se na ideia de cidade (cite) concebida por Santo Agostinho (A Cidade de Deus), eles sistematizam os traços próprios às seis cidades com as quais prescrevem tais princípios. Para tanto, recorrem às contribuições de filósofos com forte presença no imaginário da filosofia política. A sequência das cidades é a seguinte: a cidade doméstica (Bossuet - La Politique Tirée des Propres Paroles de L'Écriture Sainte); a cidade de renome (Hobbes - Leviatã); a cidade cívica (Rousseau - Do Contrato Social); a cidade mercantil (Adam Smith - The Wealth of Nations) e a cidade industrial (Saint Simon - Du Systéme Industriel). Não resta dúvida quanto à tentativa de Boltanski e Thévenot (1991) de encontrarem uma alternativa analítica e política para as consequências resultantes da policromia complexa das sociedades modernas, caracterizadas pela proliferação de esferas de experiência. Para isto, eles fazem recurso ao projeto de eticidade tendo por fundamento a provocação do cruzamento entre instâncias morais distintas entre si; cruzamento possível pela intervenção competente dos agentes. Também são notáveis os esforços de ambos para diminuir, quando não mesmo 
diluir, os efeitos da inércia histórico-institucional sobre as possibilidades criativas das agências humanas.

As formulações bourdianas e aquelas de Boltanski e Thévenot (1991) deixam ver tensões ao que parecem incontornáveis da teoria social, já que a tônica depositada na competência hermenêutica e reflexiva relativa à pragmática comunicativa do agente e como esta também se manifesta na capacidade crítica de manifestar - durante cursos conversacionais - reivindicações de justificativas de si, lastreadas em moralidades (senso de irredutíveis de bem), esbarra nas exigências da compreensibilidade e da significação. Afinal, ambas requerem repertórios sígnicos que extrapolam a particularidade de um indivíduo e, ao mesmo tempo, dependem do modo como estão distribuídos os recursos em um arranjo social amplo. Mais ainda, se são os elementos aptos a gerar diferença, sendo esta sempre relacionalmente definida, incita-nos a pergunta: como algo adquire status de recurso (os capitais financeiro, simbólico, afetivo, etc.)? Sob este ponto de vista, a atenção disposicionalista de Bourdieu (2009) aos espaços de possíveis permanence sociologicamente heurística, porque pontua o cuidado na pesquisa e análise com a formação relacional do valor dos que tomam posição nesses espaços, e com isto denunciam uma classificação identitária, em uma determinada interação. A formação do valor em simétrica relação com os fundos axiológicos da avaliação transcende os contextos intersubjetivos, avançando para elos de mediações e interdependências sociofuncionais que, a um só tempo, encontram-se nos saberes com os quais os agenciamentos se tornam tanto viáveis quanto inteligíveis enquanto usos corporais (práticas), mas igualmente nas expectativas e nos cenários em que se desenrolam as práticas recíprocas dos agentes.

A luz da tensão estabelecida entre a competência de ajuizamento e conversação dos agentes e os fatores inerciais que, sob o status de recursos necessários à continuidade prática dos comportamentos dotados de sentido, pressionam constitutivamente os agenciamentos, no que segue deste texto, examinamos a intercessão estabelecida entre justificações e posicionamentos no campo da arte do carnaval carioca, a partir da nossa experiência participativa na roda de conversa desenrolada por algumas noites, na Cidade do Samba.

Tzvetam Todorov (2011), em A Beleza Salvará o Mundo, argumenta que, por volta do século XIX, na Europa ocidental, a percepção do declínio do poder atemporal da religião fora acompanhada da ascensão de valores humanos. A seu ver, sob tal atmosfera sociossimbólica, adquiriu importância o sonho de tornar voluntariamente a vida bela e plena. A localização, por parte de Todorov (2011), do amplo compartilhamento desses ideários estéticos e estetizantes coincide com 


\section{Vidas Sob o Signo do Encanto: Ethos estético nos oficios artísticos da Arte do Carnaval Carioca}

o período de maior denodo de esforços no sentido de se obter a autonomia dos campos intelectuais e artísticos, de acordo com a narrativa sociológica de Bourdieu (1996). Fazendo uso da perspectiva de Boltanski e Thévenot (1991), diríamos que a justificação compartilhada entre aqueles(as) integrantes desses diferentes mundos artísticos em proliferação e desdobramento tem por fundamento utópiconormativo a narrativa da história da arte que advogando a singularidade do artístico (BELTING, 2006) respalda e dá suporte à prerrogativa do que chamamos de Cidade

\section{de Zaratustra.}

O motivo para o retorno ao célebre livro de Friedrich Nietzsche (1844-1900) e não a outras obras com notória repercussão na montagem do discurso estético no Ocidente, diz respeito à centralidade ocupada pelo tema da vontade criadora no discurso que encerra Assim Falou Zaratustra (NIETZSCHE, 2011). Atemosnos à síntese disposta na figura do andarilho Zaratustra - inspirado no mistagogo persa, profeta e poeta do fogo (GOMES, 2006). Ela nos vem em auxílio, porque nela, o autor prega em favor da atitude afirmativa de superação, manifesta no falar por sí próprio, não se deixando submeter às autoridades. Com isso, num gesto de rebelião heroica, a vontade de ser capaz fomenta no personagem a quebra das tábuas sagradas(dos valores), vitimando a divindade metafísica; mais que anunciar, comete o ato de matar Deus e deixa ao chão a tradição socrático-platônica imantada pela atitude intelectualista, cujo idealismo (em companhia da aposta teleológica), avesso à vida, renegaria, para fugir ao elo continuo e inquebrantável da perecividade com o renascimento. A força criadora da vontade de potência está no gesto de não tergiversar a vida como ato não redutível, tampouco substituível por qualquer modelo humano de homem. Afinal, não se trata de adorar a morte sob o disfarce do apego à divinização do espírito. Sim, obediente à coragem moral, o exercício corporal no qual se fazem cúmplices a alegria dançante musical do diritambo de ir bem adiante da conservação e a disposição guerreira de abrir caminhos, numa sucessão de atos criadores mundanos movidos pelo Amor fati (amor ao destino) de querer viver. Enfim, pela positividade da afirmação do belo, tais atos aliam a expansão ao domínio, iniciando-se com o domínio de si mesmo. No saldo da jornada dionisíaca de Zaratustra, são erguidos altares, para celebrar a vida, esta mesma atravessada pela tragédia que dispõe mútuos apogeu e declínio (SALAQUARDA, 1997; MACEDO, 1994).

Sabe-se o quanto a vida e a carreira do poeta-filósofo reuniram potências da cultura germânica e, igualmente, ele imprimiu sua marca como personagem paradigmático das concepções de arte e artístico firmadas no leito histórico-cultural da matriz europeia da modernidade. Extrapola aos objetivos deste texto ir amiude no lugar ocupado por Nietzsche como filósofo-chave à narrativa da autonomia do belo e, ainda, membro da nobreza da cultura que antecipa a modernidade estética que se levanta com a intervenção das vanguardas artísticas (HABERMAS, 
1993, COPLESTON, 1979). Importa-nos sublinhar quão sua bandeira de um individualismo soberano que, nas trilhas do romantismo, promove os sentimentos, declina ante o culto romântico do recolhimento subjetivista e da morte. A figura do superhomem, o herói da transvaloração dos valores, se ratifica a hierarquia entre superiores e fracos, o faz em nome da perseverança daquele que não se curva às hostes do utilitarismo e recusa a moral de rebanho. Vocalizada na voz poética do profeta Zaratustra, a liberdade que reclama o filósofo-poeta é uma prática contínua cujos rastros são invenções de si e de mundos (BARRENECHEA, 2000; MECA, 1989; NUNES, 1978). Ao nos referirmos à Cidade de Zaratustra, portanto, acentuamos a base canônica da plataforma normativa que informa a visão de mundo de uma ética artística fundada sobre o primado da criação e do novo. Isto, em um momento no qual as projeções utópicas e ideológicas da cultura artistica ocidental se tornam partes de quadros categoriais e lexicais, semânticos e imaginários socialmente compartilhados em meio às consequências não-programadas nas quais foram gerados padrões socioculturais admitidos como modernos.

Chama particular atenção como tais ideários sincronizados no desenho da ética particular à cultura artística do ocidente se desterritorializaram, no compasso da expansão imperial do mesmo ocidente, deixando margens às travessias transatlânticas que vicejaram múltiplas modernidades, no anverso de cruzamentos civilizatórios diversos. Deste modo, paulatinamente, esse código comportamental tornou-se parte da cidadela cognitiva e moral remontada por aqueles(as) que reclamam o reconhecimento da sua humanidade artística.

Nas noites passadas à volta das mesinhas comparticipando das rodas de conversa, por certo, apresentaram-nos tônicas, pausas, gestos, sorrisos, entre outras expressões, modos pelos quais, ao se ratificar divisões classificatórias, afirmavam posições-funções no encadeamento amplo do espaço de possíveis do carnaval, no limite, ratificando o próprio espaço. E, no mesmo andamento, nas representações arroladas nas conversações, descortinavam-se os ideários básicos do quadro de valores ali compartilhado. Não foram poucos os momentos em que se reclamou de fulano ou fulana, em razão da falta de sensibilidade para discernir que "carnaval não é teatro, nem cinema, tampouco televisão". A repreensão se pautava na evocação de uma forma artística específica, a qual serviria de parâmetro para aferir a competência na realização dos ramos de ofício aninhados nos barracões e ateliers de fantasias. E, no reverso da medalha, a mesma forma calcava as reivindicações de reconhecimento seja de individualidades artísticas, seja da unidade do grupo identificado pela rubrica artistas de carnaval.

Reclamar uma forma artística insere dois problemas, ao mesmo tempo. De um lado, requer um discurso que exponha o corpo de proposições assegurando a natureza estética a objetos, fazeres e personalidades. Logo, trata-se de um discurso comprometido com a modelação cognitiva das percepções acerca do que poderá ser 


\section{Vidas Sob o Signo do Encanto: Ethos estético nos oficios artísticos da Arte do Carnaval Carioca}

ou não elucidado pelo conceito de arte do carnaval. Mas a aplicação do discurso estético, no instante em que procura percorrer um mesmo tecido ontológico é indissociável, por outro lado, do suporte de uma moralidade exclusiva, apta no respaldo das convicções de todo(as) aqueles(as) que demandam respeito aos seus comportamentos e às materialidades expressivas; aspectos sem os quais se anulariam os contornos que diferenciam, ao mesmo tempo que totalizam, a silhueta de uma personalidade artística. Enfim, o ajuste à formação discursiva da ordem de uma ética e moral particular se manifesta condição irrefutável à segurança ontológica, na medida em que falta a representação de uma ordem transcendente plena, portanto, capaz de mensurar o valor substantivo de algo, evidenciando-o objetivo em si mesmo. Nesta ausência, tão somente resta cobrar atenção e respeito às justificativas vocalizadas por parte dos que pressionam a favor do relevo das suas existências, em especial da cumplicidade estabelecida com as respectivas aparências que as fazem tão visíveis quanto palpáveis.

Nas conversações das quais participamos na Cidade do Samba, em distintos momentos, a autoidentificação como "artista" servia para se separar dos "artesãos" ou dos "sambistas". Igualmente, o emprego da identificação permitia denunciar os arbítrios dos "poderosos" que, por meio da "grana" (dinheiro) e do emprego da "força bruta" imporiam temas aos enredos a serem desenvolvidos nos desfiles, mas também ritmos e procedimentos desumanos de trabalho, além de critérios de gostos entendidos como "estranhos", mesmo ofensivos aos parâmetros gnosiológicos e da moralidade do artista. As reclamações se estendiam ao sentimento de insegurança própria à objetividade das relações precárias de trabalho, sem base num contrato jurídico que formalizasse as obrigações referentes à remuneração e à salubridade do ambiente. Viam-se eles(as) - os(as) artistas - à mercê de mandonismos e sujeitos aos humores de líderes incautos com seus séquitos insensíveis, quando não ignorantes, às particularidades dos fazeres reunidos na arte do carnaval.

As conversações, em cada uma das noites na Cidade do Samba, testemunhavam como as retomadas da utopia da vida plena e bela cumpria a função simbólico-comunicativa de ajustar atos em favor de uma tomada de posição entre aqueles(as) que, no limite, acusam o seu compromisso com materializações, ainda que efêmera, da forma de encantamento. Vocalizado ali, naquela polifonia de posicionamentos, um código comportamental definia um ethos artístico, das vidas que prosseguem, realizando-se sob o signo do encanto. Este, a um só tempo, deixa por marca certa perenização identitária como personalidade e, no reverso da medalha, requisito à participação naquela comunidade de sentido. Na mesma medida, contribui para efetivar estratificações numa hierarquia interna, com isso incisiva quando se trata de delimitar o valor de competências e subsidiar exclusões.

Não seria exagero dizer estarem àquelas noites, nas rodas de conversa, sombreadas por alguns nomes próprios autorais artísticos, uns vivos outros já 
mortos. Ainda que outros tenham sido citados, contudo, Joãozinho Trinta, Rosa Magalhães, Renato Lage, Paulo Barros, Fernando Pamplona, Fernando Pinto, Arlindo Rodrigues, Maria Augusta Rodrigues, Max Lopes, Viriato Ferreira e Lícia Lacerda, em graus variados entre si, sempre apareciam em algumas das falas. As citações, em sua maioria, tinham por meta ilustrar argucia de cada um, no instante de resolver um problema posto na feitura de um "trabalho" (execução de um projeto de desfile). Entretanto, o emprego dos nomes não respondia a um raciocínio cumulativo, linear; ao contrário, a tendência era confrontar soluções distintas adotadas por um(a) carnavalesco(a) em relação a problemas afins. Deste modo, o João era mais "intuitivo". Já a Rosa é "mais rigorosa" no que toca à concepção dos projetos. Embora "anárquico", o Fernando (Pinto) era muito disciplinado no cotidiano do barracão. A "gente sempre sabia diferenciar o traço mais barroco do Arlindo, da mão mais geométrica do Fernando (Pamplona)". "Sem dúvida, ninguém sabe trabalhar cores melhor que o Max". "O uso de luz nas alegorias pelo Renato mudou a forma dos carros". "O Viriato mudou a concepção do figurino". "A Maria Augusta, como ninguém, consegue tirar partido da relação entre cotidiano e transcendência". A "Lícia brincava com as formas". A alta frequência de certas referências contracenava com o elenco estreito desses mesmos nomes, evidenciando o quanto difícil é passar no funil conduzindo à posição de reputada de carnavalesco(a). A reiteração dos poucos nomes, antes apresentados, nas rodas de conversa na Cidade do Samba e em outras oportunidades de interlocução ou nas mídias e nas mais variadas intervenções discursivas -, permite sugerir: a frequência com a qual cada um desses nomes era mencionado ressaltava a centralidade que ocupam no imaginário carnavalesco das escolas de samba quanto à fixação da figura do carnavalesco como autor artístico. Por isso, os chamamos de arcanos paradigmáticos. Arcanos, porque são evocados na condição de matrizes pessoais e histórico-coletiva que, ao estarem relacionadas, constituem o fundo hermenêutico dos sentidos e valores que delimitam a arte do carnaval; individualmente, eles (os nomes) são paradigmáticos em razão de representarem um modelo, um padrão com o qual prossegue a forma estética carnavalesca do gênero cultural Desfile de Carnaval, mas devido à particularização que essa individualidade impõe à concretização dessa forma. Notase, então, ser a forma a encenação deambulante de um tema enredo, entrosando para isso as dimensões plástico-visual, coreográfica e ritmo-musical. Em última instância, a celebridade gozada por cada um desses arcanos paradigmáticos advém dos respectivos tipos problematizações da forma e, na contrapartida, a solução adotada. Sobretudo, pelo chamamento, notava-se o quanto ambas se enraizaram e se tornaram perenes na modulação e continuidade da forma do gênero cultural Desfile de Carnaval.

Porém, igualmente, o cotejo dessa identificação artística surgia quando a autonarração descortinava as fragilidades institucionais cujos efeitos deixavam em 


\section{Vidas Sob o Signo do Encanto: Ethos estético nos oficios artísticos da Arte do Carnaval Carioca}

xeque a legitimidade do ser e do existir da arte e dos artistas do carnaval. Afinal, os elementos de não-seriedade (irreverência, densidade lúdica, mesma a excessiva proximidade com os planos marginais e escusos - o mecenato do jogo do bicho e do comando exercido por milícias) colocariam aquele espaço de possíveis artísticos sob suspeita de heteronomia. Pesava mesmo, em última instância, a antecedência da encomenda sobre a criação. De um lado, seriam continuamente cobrados por realizar objetos que deveriam atender às expectativas da plateia (ao vivo e mediante à transmissão de televisual e nas redes sociais da internet), sem comprometer os critérios de julgamento internos ao concurso carnavalesco do qual participam as escolas de samba. De outro, os oficiais e ofícios estão coordenados pelo calendário de realização de um evento-espetáculo tendo por natureza desfazer-se com o encerramento do ciclo festivo carnavalesco (CAVALCANTI, 2006). Logo, os produtos artísticos que dele constam estão, de antemão, submetidos à lei de ferro do efêmero.

Fazia-se notório, portanto, o quanto o lamento diante dessa efemeridade tinha por transfundo a imagem ontológica e moral da plenitude e transcendência das coisas artísticas frente aos interesses imediatistas, mas também reivindicava afiliação ao regime de autoria fundado sobre o princípio da autoria individualizada, que contracena com o predomínio antropológico da figura exemplar do gênio criador. Realçavam-se as contradições do privilégio concedido a esse regime de autoria individualizada, pois este vige em meio ao modo de produção coletivo, estando o último marcado pela ampliação das cadeias em que se posicionam as diferentes atividades na produção de um desfile de escola de samba. Cadeias estas inclusas na complexa divisão técnica do trabalho em que se distribuem as funções na cultura popular urbana carioca (FARIAS, 2017a; 2017b). Ficou-nos a suspeita de que as disputas e lutas pela afirmação e reconhecimento da individualidade das distintas personalidades artísticas, que estão à contrapartida de fóruns de visibilização e avaliação de reputações profissionais, à maneira das rodas de conversa que participamos, concretizam a amplidão espacial dessa trama de interdependências sociofuncionais. E nestas, a utópico-normativa Cidade de Zaratustra se funde à Cidade do Samba, aquele espaço de possíveis em que as pressões externas repercutem, mas traduzidas pelas crenças e os sentidos de jogar imanentes ao desenrolar das atividades interligadas que são processualizadas no cotidiano daquele local, em que se aninha a arte do carnaval. 


\section{LIVES UNDER THE SIGN OF CHARM: ETHOS AESTHETIC IN THE ARTISTIC CRAFTS OF THE ART OF CARIOCA CARNIVAL}

ABSTRACT: In this article it is important to analyze: throughout the discussion about the sociology of glory and recognition, it is possible to establish correlations between the aesthetics based on the impact of appearances on large crowds and a possible ethos crossing scales and circuits of different activities, but whose identity is strongly defined by the tonic put in the charm of the recursive conduction to the guiding senses of the entanglements of the acts?

KE YWORDS: Reputation. Art of Carnival. Ethos Artistic. Artistic Crafts. Aesthetic Culture.

\section{VIDAS BAJO EL SIGNO DEL ENCANTO: ETHOS ESTÉTICO EN LOS OFICIOS ARTÍSTICOS DEL ARTE DEL CARNAVAL CARIOCA}

RESUMEN: En este artículo importa discutir: en el curso de la discusión de la sociología de la gloria y del reconocimiento, es posible establecer las correlaciones entre una estética basada en el impacto de las apariencias en grandes multitudes y un posible ethos atravesando escalas y circuitos de diferentes actividades, pero cuya identidad está fuertemente definida por la tónica puesta en el encanto en la conducción recursiva a sentidos orientadores de los enmarañados de los actos?

PALABRAS CLAVE: Reputación. Arte del Carnaval. Ethos Artísticos. Oficios artísticos. Cultura Estética.

\section{REFERÊNCIAS}

BARRENECHEA, Miguel Angel de. Nietzsche e a Liberdade. Rio de Janeiro: 7Letras, 2000.

BELTING, Hans. O Fim da História da Arte. São Paulo: Cosac Nayfy, 2006.

BOLTANSKI, Luc e THÉVENO, Laurent. De la Justification. Les Économies de la Grandeur. Paris: Gallimard, 1991. 
Vidas Sob o Signo do Encanto: Ethos estético nos oficios artísticos da Arte do Carnaval Carioca

BOURDIEU, Pierre. O Senso Prático. Petrópolis: Vozes, 2009.

A Distinção. Porto Alegre: Zouk, 2007.

Meditações Pascalianas. São Paulo: Bertrand, 2001.

As Regras da Arte. São Paulo: Cia das Letras, 1996.

. A Economia das Trocas Linguísticas. São Paulo: Edusp, 1992.

CAVALCANTI, Maria L. V.C. Carnaval Carioca: dos bastidores ao desfile. Rio de Janeiro: UFRJ, 2006.

COPLESTON, Frederick. Nietzsche, Filósofo da Cultura. Porto: Tavares Martins, 1979.

CLIFFORD, James. A Experiência Etnográfica: antropologia e literatura no século XX. Organizado por José Reginaldo Santos Gonçalves. 2. ed. Rio de Janeiro: UFRJ, 2002.

Itinerários Transculturales. Barcelona: Gedisa, 1999.

FARIAS, Edson. "Cidade Maravilhosa","Rio Babilônia" e "Rio 40 Graus": três signos na economia simbólica da paisagem carioca. Revista de Ciências Sociais, vol. 48, no 1, p.155-207, 2017a.

. Diversidade cultural e entretenimento nas ambiências midiáticas do espetáculo.

Revista Política e Sociedade, v. 16, n. 34, 2017 b.

. Personalidade artística nos negócios mundanos: a celebração do 'gosto do povo' em Joãosinho Trinta. Sociedade e Estado, 27(3), p.594-625, 2012.

GOFFMAN, Erving. Ritual de Interação: ensaios sobre o comportamento face a face. Petrópolis: Vozes, 2011.

GOMES, Laurici Vagner. Tempo e Música em Assim falava Zaratustra: o eterno retorno como experiência musical. Dissertação (Mestrado em Filosofia) - Programa de PósGraduação em Filosofia da Universidade Federal de Minas Gerais, Belo Horizonte, 2006.

HABERMAS, Jürgen. El Discurso Filosófico de la Modernidad. Madrid: Taurus, 1993.

HEINICH, Nathalie. La Gloire de Van Gogh: essai d'Antropologie de l'Admiration. Paris: Minuit, 1991.

MALINOWSKI, Bronislaw. Argonautas do Pacífico Ocidental. São Paulo: Abril Cultura, 1976 (Os Pensadores).

MECA, Diogo Sanches. En Torno al Super-hombre - Nietzsche y la Crisis de la Modernidad. Barcelona: Editoral Antrophos, 1989. 
MACEDO, Iracema. Arte e Filosofia no "Zaratustra" de Nietzsche". Artepensamento. São Paulo: Companhia das Letras, 1994.

NIETZSCHE, Friedrich. Assim Falou Zaratustra. São Paulo: Companhia das Letras, 2011.

NUNES, Benedito. A visão romântica. In: GUINSBURG, Jacó (org.). Romantismo. São Paulo: Perspectiva, p. 51-74, 1978.

RIBEIRO, A. P. A.G., FARIAS, E., PORFÍRIO, A. "Você! Viu um carro alegórico, aí? Em busca das mediações socioculturais de um artefato artístico. Arquivos do CMD, v. 5 n. 2 , 2017.

SANTOS, Nilton S. “Carnaval é Isso Aí. A Gente Faz para Ser Destruído!": carnavalesco, individualidade e mediação cultural. Tese (Doutorado em Sociologia e Antropologia) Programa de Pós-Graduação em Sociologia e Antropologia, Universidade Federal do Rio de Janeiro, 2006.

SALAQUARDA, Jörg. A concepção básica de Zaratustra. Cadernos Nietzsche, 2, São Paulo. Departamento de filosofia USP, p.17-39, 1997.

SEARLE, John Rogers. Speech Acts: An essay in the philosophy of language. Cambridge: Cambridge University Press, 1969.

TODOROV, Tzvetan. A Beleza Salvará o Mundo. Wilde, Rilke e Tsvetana: os aventureiros do absoluto. Rio de Janeiro: Difel, 2011.

WEBER, Max. Sociologia das Religiões. Lisboa: Relógio D’Água, 2006. . Economia e Sociedade. Brasília (DF): UnB, 1992, 2 vols.

Recebido em 13/03/2019.

Aprovado em 15/04/2019. 